\title{
The question of deification in the theology of John Calvin
}

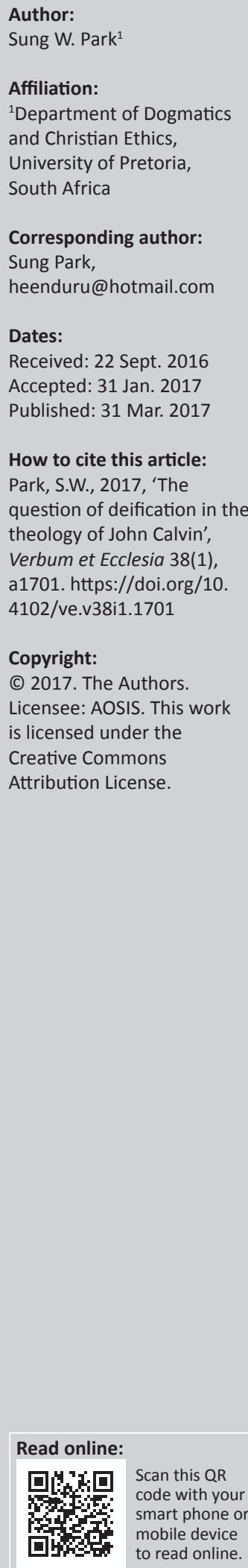

Calvin scholars debate whether Calvin's theology supports the Eastern Orthodox theosis, which advocates the believers' participation in the intrinsic divine life, mediated by Christ's humanity in their union with Christ. To attempt to give an answer to the question of theosis in Calvin's theology, this article isolates a framework used by the proponents of Eastern Orthodox theosis in Calvin's theology. The framework centres around the three aspects of the nature of the salvific gifts, the nature of the believers' union with Christ and the relation of Christ's two natures in their hypostatic union. The re-examination of these three aspects through the lens of Calvin's theology shows that it is hard to hold that Calvin teaches Eastern Orthodox theosis.

Intradisciplinary and/or interdisciplinary implication: As a Reformed intradisciplinary assessment of the question of theosis in Calvin's theology, this article maintains that the proponents of Calvin's doctrine of theosis overlook his Chalcedonian Christology, the personal dimension of his idea of union with Christ and his emphasis on Christ's salvific work in his humanity.

\section{Introduction}

Under the influence of the Christian ecumenical movement, many scholars attempted to reappropriate the idea of theosis, which has been regarded as an exclusive possession of Eastern Orthodoxy, as 'one of the oldest Christian symbols of salvation' (Kärkkäinen 2004:8). Scholars reviewed the Western theological tradition through the lens of Eastern Orthodoxy, for example, the Finnish School's 'new interpretation' of Luther's theology (Kärkkäinen 2006:75). The theology of John Calvin, who is a leading figure of the Reformed tradition, could not avoid such a tendency, either.

Many scholars, like Habets (2006:146-167, 2009:489-498) and Mosser (2002:36-57), have reinterpreted Calvin's theology in terms of theosis. The following figures can be added to the list of the proponents of (Eastern Orthodox) theosis in Calvin's theology: McClelland (1973:10-25) and Ollerton (2011:237-254). Some interpreters like Billings (2005:315-334, 2007) and Canlis (2004:169-184) insist on the uniqueness of Calvin's doctrine of theosis, which is to be differentiated from the Eastern Orthodox doctrine of theosis. This raised objections from scholars such as McCormack (2010:504-529) and Slater (2005:39-58). Garcia (2008:257-258) and Partee (2010:172-179) also reject the presence of theosis in Calvin's theology.

Therefore, the compatibility of Eastern Orthodox theosis with Calvin's theology has been an ongoing debate amongst scholars:

- Does Calvin really affirm Eastern Orthodox theosis? Are the differences in Calvin's theology and the Eastern Orthodox theosis irreconcilable?

This article approaches this question by isolating the framework behind the rationale of the positive affirmation of Calvin's doctrine of theosis. This article then examines Calvin's own teaching about the framework behind the positive affirmation.

\section{The framework for theosis in Calvin's theology}

In the present writer's view, the following three aspects constitute the framework behind the positive affirmation of Calvin's doctrine of theosis: (1) The nature of the salvific gifts like eternal life that Christ grants on his saints, (2) the nature of the believers' union with Christ and (3) the relation between Christ's two natures in their hypostatic union.

The proponents of theosis in Calvin's theology claim that the life in which believers participate in their salvation is the uncreated life which properly belongs to Christ's divinity (Mosser 2002:46; Ollerton 
2011:241, 244). The uncreated life is the divine life that flowed from Christ's divinity into the humanity assumed by the Son of God in his incarnation. By virtue of the communication of properties from the divinity to the humanity, Christ's assumed humanity partook of the divine life and was thereby deified (Habets 2006:149; Mosser 2002:46; Ollerton 2011:244).

The deified humanity of Christ is a channel through which the divine life, which was conferred on his humanity, flows to believers (Ollerton 2011:244-245). The divine life flows to believers in the context of their union with Christ: believers become the partakers of the divine life that was conferred on Christ's humanity only through their union with him (Habets 2006:149-150, 2009:492; Mosser 2002:46; Ollerton 2011:248). In this sense, Calvin's notion of the union of believers with Christ has an ontological dimension.

The scheme of the argument which affirms theosis in Calvin's theology proceeds as follows: (1) Calvin affirms the transfer of properties from Christ's divinity to his humanity in the hypostatic union that brings about the theosis of his humanity, (2) Calvin affirms the ontological dimension of believers' union with Christ, by means of which the divine life is conferred on them and (3) Thus, Calvin affirms theosis as the believers' participation in the uncreated divine life in their salvation.

This argument scheme is reiterated in a more systematic form in the theosis theory of Gregory Palamas, an authoritative source of Eastern Orthodox theosis (Collins 2010:6, 76; Russell 2004:15): the substance of theosis is the participation in the divine life (Palamas 1983:90, 106; cf. Collins 2010:101; Russell 2006:376); the basis or source of theosis is Christ's human nature, which was given the fullness of divinity through its hypostatic union with the divinity and thereby was deified (Palamas 2002:183, 192; cf. Mantzaridis 1984:30-31); the means of our theosis is the substantial union between Christ and us, in which the divine life flows to us through the channel of the deified humanity of Christ (Palamas 2002:261; cf. Meyendorff 1974:151).

In this way, the above mentioned three aspects constitute the frame of reference for the proponents of theosis in Calvin's theology. Therefore, we re-examine these three aspects in order to evaluate the validity of the argument scheme of the proponents of theosis in Calvin's theology.

\section{Calvin's understanding of the relation of Christ's two natures in the hypostatic union}

Calvin views the relation between Christ's two natures in terms of 'distinction and union'. The divine nature and the human nature are so intimately united to each other that they constitute the one Person of Christ as God and man (Calvin 1960:486-487). But the integrity of both natures is not corrupted in their union (Calvin 1959a:46, 1960:481). Therefore, Christ's two natures are inseparably yet distinctly united with each other in his Person (Calvin 1960:482).
Given that the two natures are so intimately united to each other in the Hypostasis of Christ, the scriptural ascription of the properties of one nature to the other nature (communicatio idiomatum) is 'not without reason' (Calvin 1960:1402). However, Calvin rejects the direct communication of properties from one nature to the other nature in Christ. Calvin's distinction between Christ's two natures emphasises the integrity not only of Christ's divinity but also of Christ's humanity in the hypostatic union (Extra Calvinisticum Calvin [1960:1402-1403]). The communicatio idiomatum is 'improper' in that there is no ontological co-mingling of Christ's two natures (Calvin 1999:12; cf. Tylenda 1975:58). Calvin understands the communication of properties of the two natures on the personal level (Allen 2007:393). The properties of each of the two natures are justly and appropriately ascribed to Christ's whole Person as God and man (McCormack 2010:515; Tylenda 1975:58, 60). Then, the properties of one nature may be also ascribed to the other nature only as a 'figure of speech' in the context of the hypostatic union (Calvin 1960:483).

Calvin's affirmation of the integrity of Christ's two natures in their hypostatic union seems to render impossible theosis of Christ's humanity, which is marked as the basis of our theosis by the interpreters who endorse his doctrine of theosis. Calvin does not affirm the communication of the uncreated divine life proper to God to Christ's assumed humanity.

\section{Calvin's notion of union with Christ}

To Calvin, our union with Christ is a Spirit-bonded union by faith, which has a personal and dynamic dimension, but not ontological (Niesel 1980:126; Venema 2007:88).

Although Calvin (1960:541, 570-571) insists on the reality of the union that believers have with Christ, he (1960:730, 737) also affirms that this union does not bring about any ontological mixture. Both Christ and the believers keep their own personal individuality in their union: the Chalcedonian axiom distinctio sed non separatio, which describes the hypostatic union of Christ's two natures, applies to Calvin's notion of our union with Christ.

For Calvin, the important motif which keeps the personal individuality in the context of our union with Christ is the Holy Spirit. The Holy Spirit works as the 'bond' or agent of our union with Christ (Calvin 1960:538). Firstly, the Spirit, as an inner teacher, enlightens us to receive Christ as offered through the gospel (Calvin 1960:537, 541). And the Spirit, as the Spirit of Christ (Calvin 1960:539), also communicates Christ and his salvific gifts to us. By virtue of the intimate relationship between Christ and the Holy Spirit, the indwelling of the Spirit signifies the indwelling of Christ in us (Calvin 1960:539, 1956b:94). Therefore, our union with Christ is spiritual and mystical.

The personal dimension of Calvin's notion of union with Christ is made clear by his emphasis on faith as the prerequisite on our side for the believer to enter the 
union; faith is the instrument by which the Spirit unites us to Christ (Calvin 1956a:250). This faith has a progressive character. Faith is not only initiated by the work of the Holy Spirit but also increased by degrees by the Spirit so that we enjoy more and more the intimate communion with Christ (Calvin 1960:565, 581; cf. Fisk 2009:324).

\section{Calvin's idea of the communion with Christ in the Lord's Supper}

Calvin's view of communion with Christ in the Lord's Supper is consistent with his view of union with Christ as a Spiritbonded union by faith, which has a personal and dynamic dimension.

According to Calvin's exposition (1958:207, 401-402), we truly have communion with Christ in his body and blood in the Lord's Supper. Because there is a conjunction between the external materials as signs and Christ's body and blood as the reality signified, we, by partaking of the sacramental signs, truly receive the substance of Christ's body (Calvin 1958:172, 1960:1371). Participation in the Lord's Supper in which we truly receive the substance of Christ's body confirms and strengthens our union with Christ, which was initiated through faith in the soteriological context (Calvin 1958:524).

However, unlike Lutherans, for Calvin (1960:1381-1382), the believers' eating of Christ's body is not the carnal eating of his natural body. Calvin's Chalcedonian Christology disapproves the local or corporeal presence of Christ's body (Calvin 1960:1381-1382, 1393). Rather, the believers' eating of Christ's body in the Sacrament is 'spiritual' (Calvin 1958:578). The believers become partakers of Christ's body in the Sacrament by virtue of the inner grace of the Holy Spirit: by the secret power of the Holy Spirit, the distance between the ascended body of Christ and the believers is overcome (Calvin 1958:249, 1960:1292, 2000:168). The reality of the reception of the substance of Christ's body in the Lord's Supper is the reception of the life-giving virtue of it. When the believers partake of the substance of Christ's body, they partake of the salvific grace that he acquired in his body (Calvin 1958:577; cf. Gerrish 2002:177).

The believers' partaking of Christ's body in the Supper is also carried out by our soul's ascension to the heavenly throne where Christ is seated (Calvin 1958:240, 1960:1379). In this ascension, our faith is involved in the communion. The conjunction between the sacramental signs and the substance of Christ's body is 'sacramental', not ontological (Calvin 1958:576). Therefore, when we participate in the Sacrament, we are bidden to lift up our hearts (sursum corda) and to seek Christ in heaven beyond the sacramental signs (Calvin 1958:188, 443, 1960:1412-1413).

In this way, Calvin maintains an ontological distinction between Christ and us in the spiritual, personal and dynamic union with Christ. This seems to disapprove the idea that the intrinsic divine life flows to us through the channel of Christ's humanity in our union with him.

\section{Calvin's doctrine of justification}

Calvin's doctrine of justification, a representative salvific gift conferred on the believers in their union with Christ, shows that the reception of the substance of Christ's body in the Lord's Supper is, in its reality, the same as the reception of the salvific grace that Christ acquired in his body.

For Calvin (1960:726-728), justification is God's juridical act of judging the believers as righteous solely on the basis of Christ's righteousness that is imputed to them in their union with him. This imputed righteousness of Christ in the believers' justification is not the divine essential righteousness as Osiander teaches. Instead, it is a righteousness he acquired by his obedience in his humanity to the Father through his whole life from his birth to death (Calvin 1960:507-508, 734736; cf. Venema 2007:101).

Calvin's direct answers to the three aspects of the framework behind Eastern Orthodox theosis are given in his refutation of Osiander's teaching of justification. The theological heart of Calvin's refutation of Osiander's teaching of justification is his Lutheran idea of the communicatio idiomatum. Osiander's fallacies on justification - the infusion of Christ's essential righteousness to the believers (Calvin 1960:730-732, 734; Weis 1965:34-35), the confusion of justification and sanctification (Calvin 1960:732; Vainio 2008:100; Weis 1965:34) and the essential union between Christ and the believers (Calvin 1960:737) - are derived from his Christological presupposition that Christ's human nature is mingled with his divine nature. In the mingling of the human nature and the divine nature, Christ himself became righteous by divine righteousness. And in our essential union with Christ, we are also made righteous by the divine righteousness (Garcia 2008:242-252; McCormack 2004:99; cf. Calvin 1960:737, 742).

In contradistinction of this teaching of Osiander, Calvin insists on the distinction between Christ's divine nature and his human nature in the hypostatic union: the Holy Spirit is involved in the hypostatic union as the theological safeguard for preserving the distinction between Christ's two natures (Garcia 2008:247). The Holy Spirit also becomes the bond of our union with Christ, so that the ontological distinction between Christ and us can be preserved within the union (Calvin 1960:730-731, 737). Therefore, our union with Christ does not bring about the infusion of the divine essential righteousness to us. Rather, as we are ontologically distinguished from Christ within the intimate union with him, his acquired righteousness, whilst it truly belongs to us in the context of our union with Christ, properly remains his own, that is, extra nos (Calvin 1960:741; Garcia 2009:426).

\section{Conclusion}

Calvin's own ideas about the three aspects of the framework behind Eastern Orthodox theosis seem to incapacitate any 
support of the idea of theosis as participation in the intrinsic divine life. Calvin's rejection of the direct communication of properties from Christ's divinity to his humanity renders impossible the theosis of Christ's humanity (cf. McCormack 2010:512-516; McDonnell 1967:220; Slater 2005:50). This impossibility is the basis of proponents of theosis in Calvin's theology. Furthermore, Calvin's view of the spiritual and personal union with Christ guarantees the ontological distinction between Christ and us. This ontological distinction disapproves the idea that the intrinsic divine life flows to us through the channel of Christ's humanity in our union with him (cf. McClean 2009:135-137; McCormack 2010:507-511). And it follows from Calvin's doctrine of justification that for him, the blessing conferred on the believers in their union with Christ is that which Christ acquired through his salvific work in his humanity, not that which peculiarly belongs to Christ's divinity.

Therefore, it can be reasonably concluded that as far as theosis is construed as the believers' participation in the intrinsic divine life, mediated by Christ's humanity in their union with Christ, it is hard to hold that Calvin teaches theosis.

This conclusion agrees with McCormack (2010:506) who notes that the participation in the life which is proper to God is, 'by definition, a participation in something that is essential to God'. Scholars who affirm Calvin's doctrine of theosis do not neglect Calvin's emphasis on the Creator-creature distinction: Calvin's idea of theosis as participation in the life proper to God does not imply that humans are made ontologically equal with God. But it is questionable whether the participation in the uncreated divine life does not imply participation in something that is essential to God.

Lee (2010:279) and Mosser (2002:54) take note of the similarity to the Palamite idea of the divine essence-energies distinction in Calvin's statements (1959b:371, 1960:191), in which he draws a distinction between God's 'essence' and his 'kind or quality'. They state that Palamite idea of the divine essenceenergies distinction is the motivation behind Calvin's emphasis on the Creator-creature distinction, which is kept even in believers' participation in God.

However, the Palamite idea of the divine essence-energies distinction remains a point of criticism amongst several Western theologians. ${ }^{1}$ Partee (2010:174, n.122) points out the inappropriateness of the distinction in the Reformed theology, especially in the Reformed doctrine of God's simplicity. McCormack (2010:506) doubts the validity of the distinction because the Orthodox affirmation of the participation in the uncreated divine life cannot escape to imply the participation in something that is essential to God.

The Christian ecumenical movement underlies rereading of Calvin's theology through the lens of the Eastern Orthodox doctrine of theosis. The importance of the visible unity of the churches is undeniable. The endeavour to strengthen the unity of the churches in faith and order must be encouraged as a decisive mission of the churches. Given Calvin's significant position in the Church History as a leading figure of the Reformed tradition, the Christian ecumenical movement would be reinforced by the assimilation of his theology with the Eastern Orthodox doctrine of theosis. ${ }^{2}$ However, the Christian ecumenism does not justify a truncated and forced reading of Calvin's theology. As McCormack (2010:529) cautions, failing to do justice to the full dimensions of Calvin's theology in order not to offend other churches 'short-circuits the very valuable contribution that Calvin could make' to the ecumenical dialogue.

\section{Acknowledgements Competing interests}

The author declares that he has no financial or personal relationships that may have inappropriately influenced them in writing this article.

\section{References}

Allen, R.M., 2007, 'Calvin's Christ: A dogmatic matrix for discussion of Christ's human nature', International Journal of Systematic Theology 9(4), 382-397. https://doi. org/10.1111/j.1468-2400.2007.00265.x

Billings, J.T., 2005, 'United to God through Christ: Assessing Calvin on the question of deification', Harvard Theological Review 98(3), 315-334. https://doi.org/10.1017/ S0017816005000994

Billings, J.T., 2007, Calvin, participation, and the gift: The activity of believers in union with Christ, Oxford University Press, Oxford. https://doi.org/10.1093/acprof:oso/ 9780199211876.001 .0001

Calvin, J., 1956a, Commentary on the Gospel according to John, vol. 1, transl. W. Pringle, Eerdmans, Grand Rapids, MI.

Calvin, J., 1956b, Commentary on the Gospel according to John, vol. 2, transl. W. Pringle, Eerdmans, Grand Rapids, MI.

Calvin, J., 1958, Tracts and treatises, vol.2, transl. H. Beveridge, Eerdmans, Grand Rapids, MI.

Calvin, J., 1959a, Commentary on the Epistle of Paul the Apostle to the Corinthians, vol. 2, transl. J. Pringle, Eerdmans, Grand Rapids, MI.

Calvin, J., 1959b, Commentary on the Catholic Epistles, transl. J. Owen, Eerdmans, Grand Rapids, MI.

Calvin, J., 1960, Institutes of the Christian Religion, J.T. McNeill (ed.), transl. F.L. Battles, 2 vols, Westminster Press, Philadelphia, PA.

Calvin, J., 1999, Commentary on Jeremiah and Lamentations, vol. 1, transl. J. Owen, Christian Classics Ethereal Library, Grand Rapids, MI.

Calvin, J., 2000, Calvin: Theological treatises, J.K.S. Reid (ed.), transl. J.K.S. Reid, Westminster Press, Philadelphia, PA.

Canlis, J., 2004, 'Calvin, Osiander and participation in God', International Journal of Systematic Theology6(2),169-184. https://doi.org/10.1111/j.1468-2400.2004.00127.x

Collins, P.M., 2010, Partaking in divine nature: Deification and communion, T\&T Clark International, London.

Fisk, P., 2009, 'Calvin's metaphysics of our union with Christ', International Journal of SystematicTheology11(3),309-331.https://doi.org/10.1111/j.1468-2400.2009.00451.x

Garcia, M., 2008, Life in Christ: Union with Christ and Twofold Grace in Calvin's Theology, Paternoster, Milton Keynes.

Garcia, M., 2009, 'Imputation as attribution: Union with Christ, reification and justification as declarative word', International Journal of Systematic Theology 11(4), 415-427. https://doi.org/10.1111/j.1468-2400.2009.00472.x

Gerrish, B.A., 2002, Grace and gratitude: The eucharistic theology of John Calvin, 2nd edn., T\&T Clark, Edinburgh.

Habets, M., 2006, 'Reforming theosis', in S. Finlan \& V. Kharlamov (eds.), Theosis: Deification in Christian theology, pp. 146-167, Pickwick Publications, Eugene.

Habets, M., 2009, “'Reformed Theosis?" A response to Gannon Murphy', Theology Today 65, 489-498. https://doi.org/10.1177/004057360906500407

Kärkkäinen, V.M., 2004, One with God: Salvation as deification and justification, Liturgical Press, Collegeville, PA.

Kärkkäinen, V.M., 2006, 'Salvation as justification and theosis: The contribution of the new Finnish Luther interpretation to our ecumenical future', Dialog 45(1), 74-82. https://doi.org/10.1111/j.0012-2033.2006.00296.x

2.In conclusion of his discussion on Calvin and deification, Mosser (2002:57) points out the value of Calvin's doctrine of deification for a dialogue between the Reformed and Eastern Orthodoxy as 'a point of departure' for the dialogue between them. 
Lee, Y., 2010, 'Calvin on deification: A reply to Carl Mosser and Jonathan Slater', Scottish Journal of Theology 63(3), 272-284. https://doi.org/10.1017/S0036930610000360

Mantzaridis, G., 1984, The deification of man: St. Gregory Palamas and the Orthodox tradition, transl. L. Sherrard, St. Vladimir's Seminary Press, New York.

McClean, J., 2009, 'Perichoresis, theosis and union with Christ in the thought of John Calvin', Reformed Theological Review 68(2), 130-141.

McClelland, J., 1973, 'Sailing to Byzantium', in J. Meyendorff \& J. McClelland (eds.), The new man: An orthodox and reformed dialogue, pp. 10-25, Agora Books, New Brunswick.

McCormack, B., 2004, 'What's at stake in the current debates over justification? The crisis of Protestantism in the west', in M. Husbands \& D.J. Trier (eds.), Justification: What's at stake in the current debates?, pp. 81-117, InterVarsity Press, Downers Grove, IL.

McCormack, B., 2010, 'Union with Christ in Calvin's theology: Grounds for a divinization theory?', in D.W. Hall (ed.), Tributes to John Calvin, pp. 504-529, Presbyterian \& Reformed Publishing, Phillipsburg, NJ.

McDonnell, K., 1967, John Calvin, the Church, and the Eucharist, Princeton University Press, Princeton, NJ.

Meyendorff, J., 1974, A study of Gregory Palamas, transl. George Lawrence, 2nd edn., The Faith Press, Leighton Buzzard.

Mosser, C., 2002, 'The greatest possible blessing: Calvin and deification', Scottish Journal of Theology 55, 36-57. https://doi.org/10.1017/S0036930602000133

Niesel, W., 1980, The theology of Calvin, transl. H. Knight, rev. edn., Baker Book House, Grand Rapids, MI.

Ollerton, A.J., 2011, 'Quasi Deificari: Deification in the theology of John Calvin', Westminster Theological Journal 73, 237-254.
Palamas, G., 1983, The Triads, J. Meyendorff (ed.), transl. N. Gendle, Paulist Press, Mahwah, NJ.

Palamas, G., 2002, The Homilies of Saint Gregory Palamas, vol. 1, C. Veniamin (ed.), Saint Tikhon's Seminary Press, South Canaan, PA.

Partee, C., 2010, The theology of John Calvin, paperback edn., Westminster John Knox Press, Louisville.

Russell, N., 2004, The doctrine of deification in the Greek patristic tradition, Oxford University Press, Oxford.

Russell, N., 2006, 'Theosis and Gregory Palamas: Continuity or doctrinal change?', St. Vladimir's Theological Quarterly 50(4), 357-379.

Slater, J., 2005, 'Salvation as participation in the humanity of the Mediator in Calvin's Institutes of the Christian Religion: A reply to Carl Mosser', Scottish Journal of Theology 58(1), 39-58. https://doi.org/10.1017/S003693060500092X

Tylenda, J., 1975, 'Calvin's understanding of the communication of Properties', Westminster Theological Journal 38, 54-65.

Vainio, O.P., 2008, Justification and participation in Christ: The development of the Lutheran doctrine of justification from Luther to the formula of Concord (1580), Brill, Leiden.

Vásquez, D.C., 2000, 'The mystical theology of Vladimir Lossky: A study of his integration of the experience of God into theology', PhD thesis, Department of Theology School of Religious Studies, The Catholic University of America.

Venema, C.P., 2007, Accepted and renewed in Christ: The 'Twofold Grace of God' and the interpretation of Calvin's theology, Vandenhoeck \& Ruprecht, Göttingen.

Weis, J., 1965, 'Calvin versus Osiander on justification', The Springfielder 29(3), 31-47. 